\title{
Intestinal CD103- dendritic cells migrate in lymph and prime effector T cells
}

\author{
V Cerovic $^{1}$, SA Houston ${ }^{1}$, CL Scott $^{1}$, A Aumeunier ${ }^{1}$, U Yrlid $^{2}$, AM Mowat $^{1}$ and SWF Milling $^{1}$
}

Intestinal dendritic cells (DCs) continuously migrate through lymphatics to mesenteric lymph nodes where they initiate immunity or tolerance. Recent research has focused on populations of intestinal DCs expressing CD103. Here we demonstrate, for the first time, the presence of two distinct CD103- DC subsets in intestinal lymph. Similar to CD103+ DCs, these intestine-derived CD103- DCs are responsive to Flt3 and they efficiently prime and confer a gut-homing phenotype to naive T cells. However, uniquely among intestinal DCs, CD103- CD11 b ${ }^{+} \mathrm{CX}_{3} \mathrm{CR} 1^{\text {int }}$ lymph DCs induce the differentiation of both interferon- $\gamma$ and interleukin-17-producing effector T cells, even in the absence of overt stimulation. Priming by CD103- CD11 b ${ }^{+}$DCs represents a novel mechanism for the rapid generation of effector T-cell responses in the gut. Therefore, these cells may prove to be valuable targets for the treatment of intestinal inflammation or in the development of effective oral vaccines.

\section{INTRODUCTION}

Dendritic cells (DCs) have a crucial role in maintaining the delicate balance between immunity and tolerance in the intestine. They migrate from the intestine, through lymphatics, to the mesenteric lymph nodes (MLNs) and prime the differentiation of naive T lymphocytes into regulatory or effector cells. Understanding the functions of intestinal DCs is crucial for the development of oral vaccines and the treatment of inflammatory bowel disease. However, the precise identification of intestinal DCs is hindered by several factors. First, isolation of cells from the intestinal lamina propria (LP) necessitates mechanical and enzymatic disruption of tissue, which could alter the phenotype of isolated cells and may preferentially purify particular cell types. ${ }^{1}$ Second, macrophages share many phenotypic characteristics with DCs, rendering surface marker expression alone inappropriate for unequivocal identification of DC populations. Importantly, intestinal macrophages do not migrate from the intestine to MLNs but remain in the LP, where they maintain and amplify the effector functions of $\mathrm{T}$ cells that migrate to the LP after being primed in the MLNs. ${ }^{2}$

Recently, a subset of CD103 (integrin $\alpha \mathrm{E}$ )-expressing CD11c ${ }^{+}$ $\mathrm{MHCII}^{+}$(major histocompatibility complex II) LP cells has generated substantial interest. These $\mathrm{CD} 103^{+} \mathrm{LP}$ cells are likely to represent bona fide DCs as they develop independently of M-CSF (macrophage colony-stimulating factor) but expand in response to fms-like tyrosine kinase 3 ligand (Flt3L) and granulocyte M-CSF. ${ }^{3,4} \mathrm{CD}_{103^{+}}$LP DCs express CCR7, and cells of a similar phenotype and function are present in the MLN. $\mathrm{CD}_{103}{ }^{+} \mathrm{DCs}$ from both the LP and the MLN induce differentiation of naive $\mathrm{CD}^{+}{ }^{+} \mathrm{T}$ cells into $\mathrm{FoxP} 3^{+}$regulatory $\mathrm{T}$ cells, ${ }^{5,6}$ and drive responding $\mathrm{T}$ cells to express the gut-homing molecules CCR9 and $\alpha 4 \beta 7.7$

Intestinal $\mathrm{CD} 103^{+} \mathrm{DCs}$ are a heterogeneous population of cells and can be divided into two functionally distinct subsets: $\mathrm{CD}_{11} \mathrm{~b}^{+} \mathrm{CD} 8 \alpha^{-}$and CD $11 \mathrm{~b}^{-} \mathrm{CD} 8 \alpha^{+} .{ }^{8,9}$ The CD $8 \alpha^{+} \mathrm{DCs}$ represent a smaller subset of LP DCs, ${ }^{3,9}$ and it is currently not clear whether they migrate in lymph or contribute to priming of naive cells in the MLN. ${ }^{10}$

In contrast to $\mathrm{CD} 103^{+} \mathrm{DCs}, \mathrm{CD} 103^{-}$DCs in the MLN are reported to have a more immunogenic phenotype in both the steady state ${ }^{5}$ and in inflammation. ${ }^{11}$ However, these CD103MLN DCs are thought to originate from the blood and not from the intestine. Whether any CD103- DCs migrate from the LP to the MLN, and the role they may have in the induction of immune responses is currently a matter of controversy. The majority of $\mathrm{CD} 11 \mathrm{c}^{+} \mathrm{MHCII}^{+} \mathrm{CD} 103^{-} \mathrm{LP}^{-}$cells express high levels of the chemokine receptor $\mathrm{CX}_{3} \mathrm{CR} 1$ and, while they have been referred to as DCs, ${ }^{3,12}$ several lines of evidence have called this classification into question. Small intestinal (SI) LP $\mathrm{CX}_{3} \mathrm{CR} 1^{\text {hi }} \mathrm{CD}_{103}{ }^{-}$cells express $\mathrm{F} 4 / 80,{ }^{4}$ develop from monocytes in an M-CSF-dependent manner ${ }^{3}$ and, crucially, are absent

${ }^{1}$ Institute for Infection, Immunity \& Inflammation, College of Medical, Veterinary and Life Sciences, University of Glasgow, Glasgow, UK. ${ }^{2}$ Department of Medical Microbiology and Immunology, University of Gothenburg, Gothenburg, Sweden. Correspondence: V Cerovic (vuk.cerovic@glasgow.ac.uk) 
from afferent intestinal lymph. ${ }^{4}$ On balance, it is likely that these $\mathrm{CD}_{11 \mathrm{c}^{+}} \mathrm{MHCII}^{+} \mathrm{CX} 3 \mathrm{CR} 1^{\text {hi }}$ cells represent intestinal macrophages. ${ }^{13}$

Although $\mathrm{CD}_{103^{-}}$DCs are commonly found in peripheral tissues, it is not clear whether there are any bona fide $\mathrm{CD}_{103}{ }^{-}$ DCs in the intestinal LP. ${ }^{14}$ Intriguingly, a population of MHCII ${ }^{\text {hi }}$ $\mathrm{CD} 11 \mathrm{c}^{+}$cells expressing intermediate levels of $\mathrm{CX}_{3} \mathrm{CR} 1$ appears distinct from $\mathrm{CX}_{3} \mathrm{CR}_{1}{ }^{\mathrm{hi}}$ macrophages. These cells are phenotypically heterogeneous and their exact functions remain unclear. ${ }^{4,15}$ Although the majority appear to have the phenotypic and functional properties characteristic of inflammatory macrophages, ${ }^{16}$ some may also share the Flt3-dependent ontogeny characteristic of DCs. ${ }^{4}$

Here, we have used a novel approach to define intestinal DCs based on their ability to migrate in steady-state intestinal lymph. We are therefore able to offer a definitive and comprehensive characterization of the phenotype and function of all intestine-derived, lymph-borne DCs (LDCs). We show that, in addition to $\mathrm{CD}_{103}{ }^{+} \mathrm{DCs}$, two distinct subsets of $\mathrm{CD} 103^{-} \mathrm{DCs}$ constitutively migrate to the MLN. Furthermore, these CD103DCs have Flt3-dependent ontogeny, are highly effective antigenpresenting cells, and can confer gut tropism to naive $\mathrm{T}$ cells. Notably, in contrast to the $\mathrm{CD} 103^{+}$-migrating DCs, $\mathrm{CD} 103^{-}$ intestinal LDCs induce differentiation of interferon (IFN)- $\gamma$ and interleukin (IL)-17-producing effector T cells.

\section{RESULTS \\ Intestinal CD103+ CD8 $\alpha^{+}, \mathrm{CD}_{103}{ }^{+} \mathrm{CD} 11 \mathrm{~b}^{+}$, and CD103- DCs migrate in lymph}

A fundamental and defining feature of intestinal DCs is that they are able to migrate from the intestinal LP to the MLN through the intestinal lymphatics. We have adapted techniques previously used in rats ${ }^{17}$ and mice ${ }^{18,19}$ to isolate migrating intestinal DCs from murine thoracic duct lymph. ${ }^{20}$ Unlike direct isolation of cells from afferent mouse intestinal lymphatics, ${ }^{4}$ thoracic duct cannulation yields sufficient numbers of cells for direct functional analyses of purified DC subsets, and allows the collection of all MLN-bound DCs over a period of time. Very few, if any, DCs migrate from lymph nodes via efferent lymphatics and the thoracic duct lymph of normal mice is largely devoid of CD11c ${ }^{+}$ cells (Figure 1a). Six weeks after mesenteric lymphadenectomy (MLNx), the re-anastomosis of lymphatics allows "pseudoafferent lymph" DCs to migrate from the intestine into the thoracic duct. Thoracic duct lymph from mice after mesenteric lymphadenectomy, therefore, contains a distinct population of $\mathrm{CD}_{11 \mathrm{c}^{+}} \mathrm{MHCII}^{\mathrm{hi}}$ cells, (Figure 1a) which represent DCs migrating from the intestine to the MLN.

Our analysis of these intestinal LDCs revealed a heterogeneous population of cells comprising at least three subsets, based on their expression of CD103, CD11b, and CD8 $\alpha$ (Figure 1b,c). As expected, the majority of LDCs expressed CD103; these could be split into two subsets: $\mathrm{CD} 103^{+} \mathrm{CD} 11 \mathrm{~b}^{+} \mathrm{CD} 8 \alpha^{-}$(described

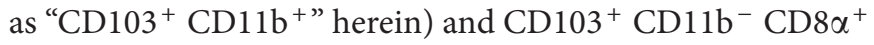
("CD103 $\left.{ }^{+} \mathrm{CD} 8 \alpha^{+"}\right)$. A smaller subset $(14.2 \pm 4.2 \%)$ of migrating DCs did not express CD103 (Figure 1b,c). The three LDC subsets had distinct morphology. Although the $\mathrm{CD} 103^{+} \mathrm{CD} 8 \alpha^{+}$
LDCs displayed prominent "spiny" dendrites, the $\mathrm{CD} 103^{-}$and $\mathrm{CD}_{103}{ }^{+} \mathrm{CD} 11 \mathrm{~b}^{+}$LDCs had ruffled cell membranes, with shorter, more evenly-spaced protrusions (Figure 1d). The expression of CD172a (SIRP $\alpha$ ) has been used to identify DC subsets in many mammalian species. ${ }^{20}$ Here, we observed uniformly high levels of CD172a expression on $\mathrm{CD}_{103}{ }^{+} \mathrm{CD} 11 \mathrm{~b}^{+} \mathrm{LDCs}$ and the majority of $\mathrm{CD} 103^{-}$LDCs. By contrast, CD8 $\alpha$ expression was confined to $\mathrm{CD} 103^{+} \mathrm{CD} 11 \mathrm{~b}^{-} \mathrm{CD} 8 \alpha^{+}$LDCs. CD4 was expressed at similarly low levels on all three LDC subsets (Figure 1e). None of the LDCs expressed the pDC-specific marker plasmacytoid dendritic cell antigen 1 (PDCA-1) (Figure 1e), confirming that $\mathrm{pDCs}$ do not migrate from rodent intestinal mucosa. ${ }^{21}$ Interestingly, both the $\mathrm{CD} 103^{-}$DCs and the $\mathrm{CD}_{103}{ }^{+} \mathrm{CD}_{11 \mathrm{~b}^{+}}$LDCs expressed low levels of F4/80 (Figure 1e). $\mathrm{CD} 03^{+} \mathrm{CD} 1 \mathrm{~b}^{+}$LDCs also expressed low levels of Siglec F (Figure 1e), normally considered an eosinophil-specific marker. ${ }^{22}$ However, their morphological characteristics and high levels of MHCII expression clearly mark LDCs as distinct from eosinophils. All three subsets of LDCs had a surface phenotype previously described as "semi-mature", 23 expressing high levels of surface MHCII but low levels of the costimulatory molecules CD40, CD80, and CD86 (Figure 1e).

\section{CD103- LDCs efficiently prime CD4 ${ }^{+}$and $\mathrm{CD}^{+}{ }^{+}$naive $\mathrm{T}$ cells}

Our analysis of lymph cells revealed the presence of a significant number of $\mathrm{CD}_{103^{-}}$cells, which possess the phenotypic and migratory hallmarks of DCs. We next examined whether migratory $\mathrm{CD}_{103^{-}}$cells possessed the other defining property of DCs, the ability to present antigen to naive T cells. To do this, the three subsets of LDCs were sorted, pulsed with ovalbumin, and co-cultured with CFSE (carboxyfluorescein succinimidyl ester)-labeled, naive OVA-specific OT- $1\left(\mathrm{CD}^{+}\right)$or OT-2 $\left(\mathrm{CD} 4^{+}\right)$TCR-transgenic T cells. As expected, $\mathrm{CD} 103^{+} \mathrm{LDCs}$ could induce antigen-specific proliferation of $\mathrm{T}$ cells, although they differed markedly in their ability to present antigen to $\mathrm{CD}^{+}$and $\mathrm{CD} 8{ }^{+} \mathrm{T}$ cells. Although $\mathrm{CD} 103^{+} \mathrm{CD} 11 \mathrm{~b}^{+} \mathrm{LDCs}$ were more efficient than $\mathrm{CD} 103^{+} \mathrm{CD} 8 \alpha^{+}$LDCs at inducing proliferation of naive $\mathrm{CD} 4^{+} \mathrm{T}$ cells (Figure 2a,b), $\mathrm{CD} 103^{+}$ $\mathrm{CD}_{11 b^{+}}$LDCs were less effective than $\mathrm{CD} 103^{+} \mathrm{CD} 8 \alpha^{+}$LDCs at cross-presenting antigen to naive $\mathrm{CD} 8^{+} \mathrm{T}$ cells, especially at lower DC:T cell ratios (Figure 2c,d). Unexpectedly, the CD103LDCs were better at inducing proliferation of antigen-specific naive $\mathrm{CD} 4{ }^{+} \mathrm{T}$ cells than either $\mathrm{CD} 103^{+} \mathrm{LDC}$ subset, and were almost as efficient as CD8 $\alpha^{+}$DCs at cross-presentation (Figure 2a-d). Therefore, their priming efficiency, as well as their migration pattern unambiguously identifies $\mathrm{CD} 103^{-}$LDCs as bona fide DCs.

\section{LDC subsets express aldehyde dehydrogenase and induce CCR9 expression on proliferating T cells}

These data indicate that although $\mathrm{CD} 103^{-}$LDCs comprise a relatively small proportion of migrating DCs, they may have a significant effect on the T-cell response initiated in the MLN. We therefore explored their effects on the functional differentiation of naive T cells in vitro. A hallmark of $\mathrm{CD}_{103}{ }^{+} \mathrm{DCs}$ from the LP and MLN is that they confer a gut-homing phenotype on 


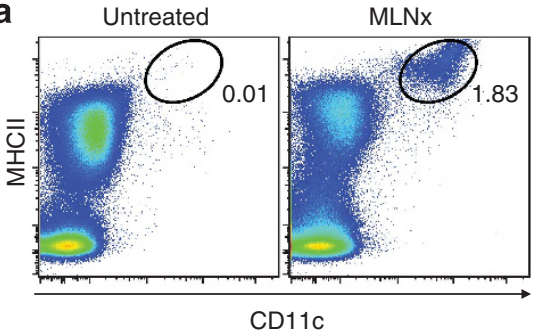

b

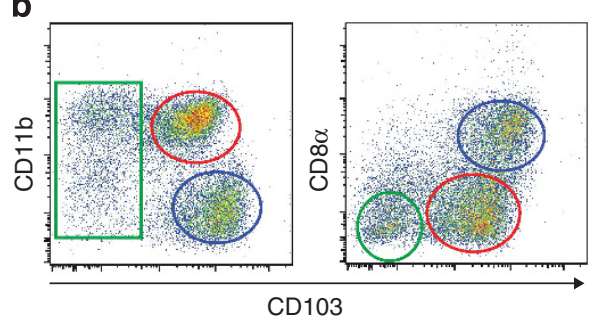

C

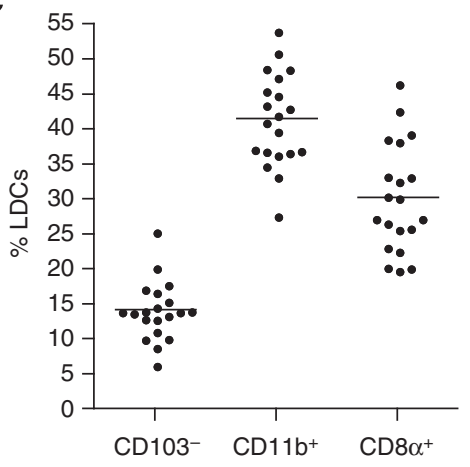

d

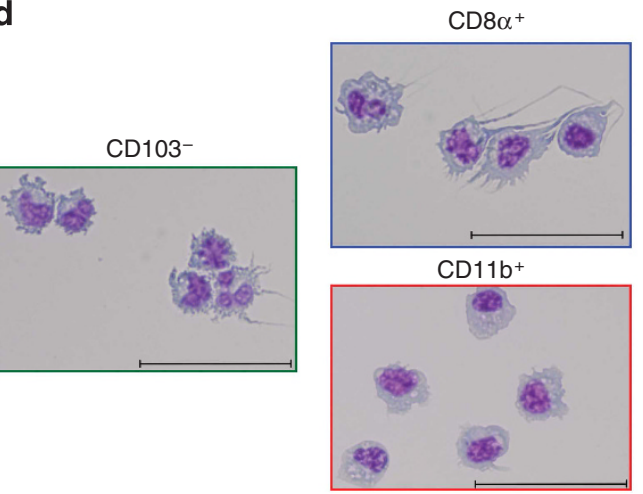

e

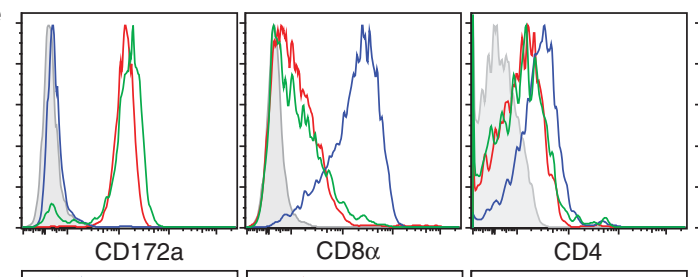

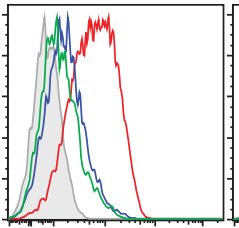

Siglec F

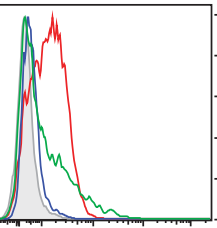

$\mathrm{F} 4 / 80$

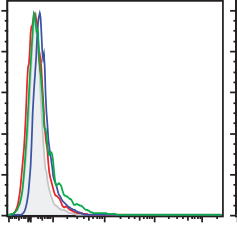

PDCA-1

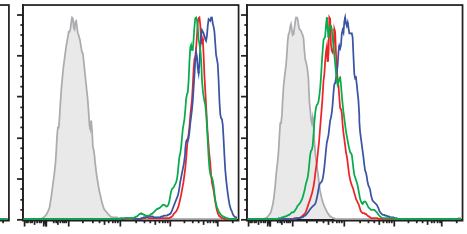

MHCII

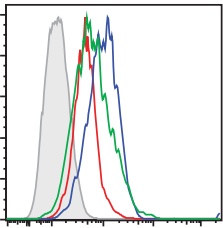

CD80
CD40

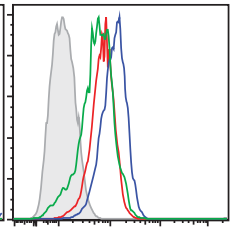

CD86

Figure 1 Phenotype of intestinal lymph-borne mouse dendritic cells (LDCs). Thoracic duct cannulation was performed on 12-week-old MLNx (mesenteric lymphadenectomy) C57BI6 mice and lymph collected for $16 \mathrm{~h}$, on ice. Lymph cells were washed and stained for multi-color flow cytometry. (a) DCs, identified as $\mathrm{CD} 11 \mathrm{c}^{+} \mathrm{MHCI} \mathrm{I}^{\mathrm{hi}}$, were absent in efferent lymph of untreated mice but present in pseudo-afferent lymph of MLNx mice. Numbers show the percentage of live cells. (b) CD11 ${ }^{+} \mathrm{MHCI}^{\text {hi }}$ cells can be divided into three subsets based on the expression of CD103, CD11b, and CD8 $\alpha$. (c) Percentage of the three subsets of LDCs within the $\mathrm{CD}_{11 \mathrm{C}^{+}} \mathrm{MHCI}^{\mathrm{hi}}$ population. Each dot represents an independent experiment. (d) The three LDC subsets were gated as in (b) and sorted by fluorescence-activated cell sorter. The sorted cells were spun onto slides and stained to observe the morphology. Bar $=50 \mu \mathrm{m}$. (e) Expression of a range of phenotypic markers plasmacytoid dendritic cell antigen 1 (PDCA-1), major histocompatibility complex II (MHCII), and costimulatory molecules CD40, CD80, and CD86 on LDC subsets. The histograms show the expression of the indicated marker on $\mathrm{CD}_{103}{ }^{-}$(green), $\mathrm{CD} 103^{+} \mathrm{CD} 11 \mathrm{~b}^{+}$(red), and CD103 ${ }^{+} \mathrm{CD} 8 \alpha^{+}$(blue) cells. The filled histogram represents the appropriate isotype control gated on total $\mathrm{CD} 11 \mathrm{c}^{+} \mathrm{MHClI}^{\mathrm{hi}}$ cells. Results in (d) and (e) are representative of three independent experiments.

interacting T cells, by virtue of their ability to metabolize dietary vitamin A into retinoic acid. ${ }^{7,24}$ We examined LDCs for the activity of aldehyde dehydrogenase, an enzyme required for retinoic acid generation, as measured by the fluorescence of the ALDEFLUOR substrate. All three subsets of intestinal LDCs exhibited high levels of aldehyde dehydrogenase activity, which was blocked by the specific inhibitor diethylaminobenzoaldehyde (Figure 3a,b). Moreover, when cultured with antigen-specific naive CD8 ${ }^{+} \mathrm{T}$ cells, all three LDC subsets were able to induce CCR9 expression on dividing T cells (Figure 3c).
Therefore, the $\mathrm{CD}_{103^{-}}$and $\mathrm{CD} 103^{+}$intestinal LDC populations share the ability to confer gut tropism to differentiating $\mathrm{T}$ cells.

\section{CD103- LDCs induce differentiation of IFN- $\gamma$ - and IL-17-producing T cells}

To further investigate the functions of LDC subsets, we compared their ability to drive naive $\mathrm{CD} 4^{+}$and $\mathrm{CD} 8^{+} \mathrm{T}$ cells to adopt an effector phenotype. As expected, both $\mathrm{CD} 4^{+}$ and $\mathrm{CD} 8^{+} \mathrm{T}$ cells primed with either subset of CD103 ${ }^{+} \mathrm{LDCs}$ produced little or no IFN- $\gamma$ or IL-17 (Figure 4a,b) and low 
a
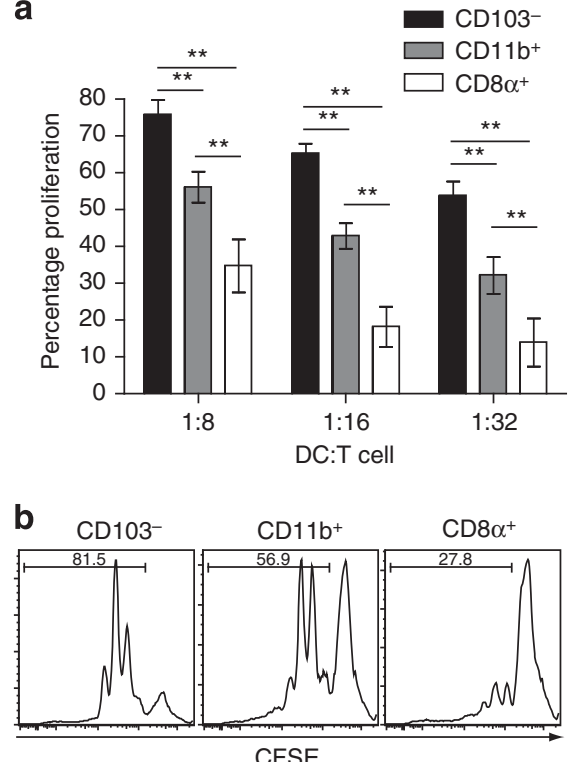

C
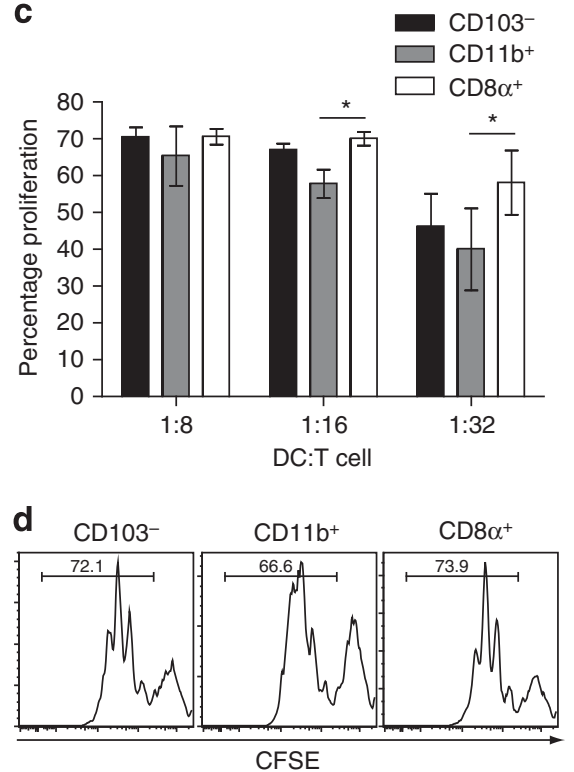

Figure 2 Subsets of lymph-borne dendritic cells (LDCs) prime and cross-prime naive T cells with different efficiencies. CD103- ${ }^{-}$CD103 $3^{+}$CD11 $\mathrm{b}^{+}$, and $\mathrm{CD} 103^{+} \mathrm{CD} 8 \alpha^{+} \mathrm{LDCs}$ were sorted by fluorescence-activated cell sorter and incubated for $2 \mathrm{~h}$ with $2 \mathrm{mg} \mathrm{ml}^{-1}$ of ovalbumin protein. DCs were extensively washed and plated out at a range of dilutions with $10^{5}$ carboxyfluorescein succinimidyl ester (CFSE)-labeled (a and $\left.\mathbf{b}\right)$ sorted CD4 ${ }^{+}$ $\mathrm{CD}_{2} \mathrm{~L}^{+} \mathrm{OT}-2$ cells or $(\mathbf{c}$ and $\mathbf{d}) \mathrm{CD}^{+} \mathrm{CD}^{+} \mathrm{L}^{+}$OT-1 cells for 3 days. Proliferation was assessed by CFSE dilution. (a and $\left.\mathbf{c}\right)$ Data are presented as mean \pm s.d. and are pooled from four independent experiments. Asterisks denote statistical significance $\left({ }^{*} P<0.05,{ }^{* *} P<0.01\right)$. (b and d) Examples of CFSE dilution induced by the three LDC subsets at 12,500 DCs per well.

levels of IL-10 or IL-4 (data not shown). However, IFN- $\gamma$ production from $\mathrm{CD}^{+}{ }^{+} \mathrm{T}$ cells was enhanced if the CD103 ${ }^{+} \mathrm{LDC}$ were first stimulated with bacterial lipoprotein, a Toll-like receptor 2 agonist (Figure 4b). Bacterial lipoprotein-stimulated CD103+ LDCs also induced increased T-cell proliferation, compared with unstimulated LDCs (data not shown).

In marked contrast to both $\mathrm{CD} 103^{+} \mathrm{LDC}$ subsets, steady-state $\mathrm{CD}_{103}{ }^{-} \mathrm{DC}$ induced both $\mathrm{CD} 4^{+}$and $\mathrm{CD} 8^{+} \mathrm{T}$ cells to produce high concentrations of IFN- $\gamma$, even in the absence of overt stimulation (Figure 4a,b). Furthermore, CD103- LDCs were the only LDCs to induce IL-17 production by both OT-1 and OT-2 cells. Freshly isolated LDC subsets expressed very low mRNA levels of IL-12 and IL-23 subunits (data not shown); however, when cultured with an agonistic anti-CD40 antibody to mimic their interaction with cognate T cells, CD103- ${ }^{-}$LDCs expressed at least 10-fold more mRNA for IL-12p40, IL-12p35, and IL-23p19, (Figure 4c). These data strongly suggest that expression of these cytokines confers the CD103- LDCs with their capacity to drive immunogenic T-cell differentiation.

All LDC populations expressed very low levels of the IL-10 mRNA, even after culture with the anti-CD40 antibody (data now shown), in contrast to the intestinal macrophage populations. $^{25}$

\section{CD103- DCs comprise two distinct subsets in steady-state lymph and SI LP}

Having identified CD103- ${ }^{-}$LDCs as a novel migratory population of intestinal DCs, we sought to identify cells with a similar phenotype in the intestinal LP of $\mathrm{CX}_{3} \mathrm{CR} 1^{\text {gfp } /+}$ mice. ${ }^{26}$ Having first excluded macrophages based on their distinct $\left(\mathrm{MHCII}^{+}\right.$ F4/80 ${ }^{\text {hi }} \mathrm{CX}_{3} \mathrm{CR}{ }^{\text {hi }}$ ) phenotype (MФ; Figure 5a), we were able to identify DC subsets similar to those in lymph (Figure 5a, see Supplementary Figure S1 online). In both lymph and LP, $\mathrm{CD}_{103}{ }^{+} \mathrm{DC}$ were $\mathrm{CX}_{3} \mathrm{CR} 1^{-}$(P3, P4; Figure 5b). By contrast, the $\mathrm{CD}_{103^{-}} \mathrm{DC}$ population in both sites was heterogeneous

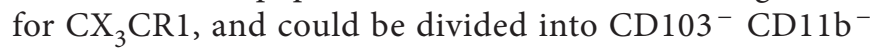
$\mathrm{CX}_{3} \mathrm{CR}^{-}(\mathrm{P} 1)$ and $\mathrm{CD}^{-} 03^{-} \mathrm{CD}^{-1} \mathrm{~b}^{+} \mathrm{CX}_{3} \mathrm{CR}^{+}$(P2) populations (Figure 5a,b). The majority of $\mathrm{CD}_{103^{-}} \mathrm{CD}_{11 \mathrm{~b}^{+} \mathrm{DCs}}$ expressed $\mathrm{CX}_{3} \mathrm{CR} 1$ at similar levels to the previously described $\mathrm{CX}_{3} \mathrm{CR} 1^{\text {int }} \mathrm{LP}$-cell population and notably lower than the $\mathrm{CX}_{3} \mathrm{CR} 1^{\text {hi }}$ macrophages (Figure 5b). ${ }^{4,15}$ Importantly, all four LP DC populations, including both $\mathrm{CD}_{103^{-}}$and both $\mathrm{CD} 103^{+}$ subsets, expressed similar levels of CCR7 mRNA, which was almost 10-fold higher than that found in LP macrophages (Figure 5c). All LP DC populations expressed very low levels of IL-10 mRNA (data not shown).

In order to gain a better understating of the biology of these phenotypically distinct, migrating DC subsets, we next examined their anatomical origins in the intestine. To do this, we made use of ROR $\gamma \mathrm{t}^{-/-}$mice, which lack all secondary lymphoid tissues except the spleen and so are devoid of Peyer's patches, and isolated lymphoid follicles. ${ }^{27}$ Despite previous reports that

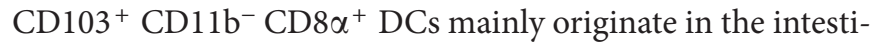
nal lymphoid tissues, ${ }^{10}$ they comprise a normal proportion of LDCs and are present in normal numbers in the LP of ROR $\gamma \mathrm{t}^{-/-}$ mice (Figure 5d). Similarly, the $\mathrm{CD}_{103}{ }^{+} \mathrm{CD} 11 \mathrm{~b}^{+}$and $\mathrm{CD} 103^{-}$ $\mathrm{CD}_{11 \mathrm{~b}^{+}}$populations were unchanged in $\mathrm{ROR} \gamma \mathrm{t}^{-/-}$mice (Figure 5d). By contrast, the $\mathrm{CD}_{103^{-}} \mathrm{CD} 11 \mathrm{~b}^{-}$population 
a
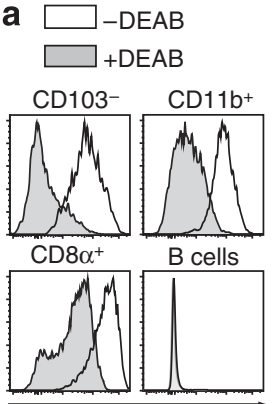

ALDEFLUOR

C
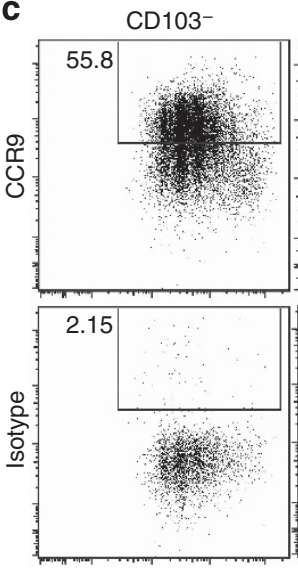

b
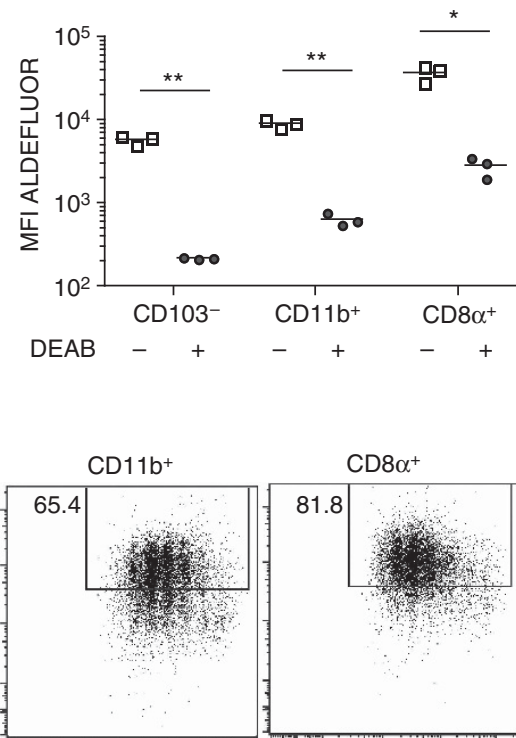

3.7
3.7

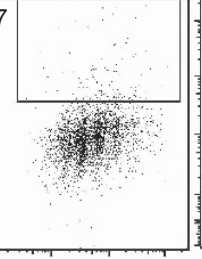

CFSE

Figure 3 Lymph-borne dendritic cell (LDC) subsets show aldehyde dehydrogenase (ALDH) activity and can induce CCR9 expression on responding T cells. (a) Lymph cells were incubated with the fluorescent ALDH substrate ALDEFLUOR and stained for flow cytometry. The three LDC subsets were gated as in Figure 1, and lymph B cells (CD19+ $\mathrm{MHCll}^{+}$) were used as a negative control. Histograms represent green fluorescence in the presence (grey-filled histograms) or absence (white histograms) of the ALDH inhibitor diethylaminobenzoaldehyde (DEAB). (b) Mean fluorescence intensity (MFI) of ALDEFLUOR in the three subsets of LDCs in the presence (filled circles) or absence (open squares) of DEAB. Each dot represents an individual biological replicate. (c) LDC subsets were sorted by fluorescence-activated cell sorter, incubated for $2 \mathrm{~h}$ with $2 \mathrm{mg} \mathrm{ml}^{1}$ of ovalbumin protein, washed, and plated out at 1:8 DC:T cell ratio with $10^{5}$ carboxyfluorescein succinimidyl ester (CFSE)-labeled sorted naive CD8 ${ }^{+}$OT- 1 cells and cultured for 3 days. Proliferating $T$ cells were analyzed for the expression of CCR9. All data are representative of three independent experiments.

was significantly reduced in the lymph and LP of ROR $\gamma \mathrm{t}^{-1-}$ mice (Figure 5d), indicating that the majority of these DCs may derive from organized intestinal lymphoid tissues, and not from the LP.

To ascertain whether both $\mathrm{CD} 103^{-}$subpopulations contribute to the priming of effector $\mathrm{CD} 4{ }^{+} \mathrm{T}$ cells, they were sorted and incubated with ovalbumin and naive OT-II T cells. Analysis of the supernatants revealed that both CD103- ${ }^{-}$LDC subsets induced IL-17 production from the OT-II T cells; however, the capacity to induce IFN- $\gamma$ production was confined to the $\mathrm{CD}_{103^{-}} \mathrm{CD}_{11 \mathrm{~b}^{+}}$subset of LDCs (Figure 5e). As before, neither of the $\mathrm{CD}_{103}{ }^{+}$subsets could stimulate production of either IFN- $\gamma$ or IL-17.

\section{CD103- DCs in the SI LP and intestinal lymph expand in response to FIt3L}

To address the ontogeny of LDC subsets, mice were treated with recombinant Flt3L for 9 days before cannulation of the thoracic duct. This led to a significant increase in the frequency of all four DC subsets, both in the lymph (Figure 6a) and the SI LP (Figure 6b), but had no effect on F4/80 $/ 8 \mathrm{MHCI}^{\text {hi }} \mathrm{LP}$ macrophages (Figure $\mathbf{6 b}$ ). These results support previous work showing the selective effect of Flt3L on SI LP CD103 ${ }^{+}$DCs and CD103- DCs but not the $\mathrm{CX}_{3} \mathrm{CR} 1^{\text {hi }}$ macrophages. ${ }^{4} \mathrm{PCR}$ analysis of growth factor receptor expression confirmed these findings by showing that all four subsets of LP DCs expressed 100-fold more Flt3 mRNA than LP macrophages (Figure 6c). By contrast, LP DCs expressed at least 10-fold less colony-stimulating factor 1 receptor mRNA than macrophages. Taken together, these experiments offer further evidence that the migrating $\mathrm{CD} 103^{-}$cells we identified represent genuine DCs, detectable in the steady-state lymph and LP.

\section{DISCUSSION}

Intestinal DCs and macrophages share a number of phenotypic and functional features, which has made the elucidation of their respective roles in the initiation of peripheral tolerance and induction of immune responses challenging. ${ }^{1}$ However, an important functional distinguishing feature of DCs is their ability to migrate in lymph to the draining MLNs. Here, we sought to examine the phenotype and function of mouse intestinal DCs by direct examination of $\mathrm{CD}_{11 \mathrm{c}^{+}} \mathrm{MHCII}^{+}$cells in intestinal pseudo-afferent lymph. Our studies revealed the existence of three distinct subset of migrating DCs: $\mathrm{CD} 103^{+} \mathrm{CD} 11 \mathrm{~b}^{+}$, $\mathrm{CD}_{103}{ }^{+} \mathrm{CD} 8 \alpha^{+}$, and $\mathrm{CD}_{103}{ }^{-}$. These findings are novel and surprising for a number of reasons. First, while CD103 ${ }^{+}$ $\mathrm{CD} 11 \mathrm{~b}^{+}$DCs make up the majority of $\mathrm{CD} 103^{+}$LP DCs in the small intestine and their migration to the MLN has been well documented, ${ }^{3,8,10}$ the fate of $\mathrm{CD} 103^{+} \mathrm{CD} 8 \alpha^{+}$DCs is less clear. Although a distinct subset of $\mathrm{CD} 103^{+} \mathrm{LP}$ DCs has recently been shown to express $\mathrm{CD} 8 \alpha,{ }^{9}$ and fewer $\mathrm{CD} 8 \alpha^{+}$DCs are found in the MLNs of CCR $7^{-1-}$ mice, ${ }^{28} \mathrm{CD} 8 \alpha^{+} \mathrm{DC}$ are generally thought to reside mostly within secondary lymphoid organs and not to migrate in lymph. ${ }^{10}$ To our knowledge, the data shown here represent the first definitive evidence that $\mathrm{CD} 103^{+} \mathrm{CD} 8 \alpha^{+} \mathrm{DCs}$ constitutively migrate from the intestine to the MLN.

Moreover, the $\mathrm{CD} 103^{+} \mathrm{CD} 11 \mathrm{~b}^{-} \mathrm{CD} 8 \alpha^{+} \mathrm{DCs}$ were present in normal numbers in the lymph and LP of ROR $\gamma \mathrm{t}^{-1-}$ mice, which lack Peyer's patches and isolated lymphoid follicles, indicating that the majority of these DCs derive from the LP of the conventional villus mucosa. The $\mathrm{CD} 8 \alpha^{+} \mathrm{LDCs}$ were especially effective at cross-presentation to $\mathrm{CD} 8^{+} \mathrm{T}$ cells, and far less effective at priming $\mathrm{CD} 4^{+} \mathrm{T}$ cells than $\mathrm{CD} 8 \alpha^{-}$LDCs. Similar specialization of CD $8 \alpha^{+}$and $\mathrm{CD} 8 \alpha^{-}$DCs has been described in other tissues, including the SI LP. 8,9

Our second important finding was of a significant number of CD103- DCs in intestinal lymph, suggesting that CD103 cannot be used as a de-facto marker of migratory intestinal DCs in MLN, as has become convention. ${ }^{4,5,9,24}$ Although $\mathrm{CD}_{103}{ }^{-}$cells make up the majority of $\mathrm{CD} 11 \mathrm{c}^{\text {hi }} \mathrm{MHCII}^{+}$cells 

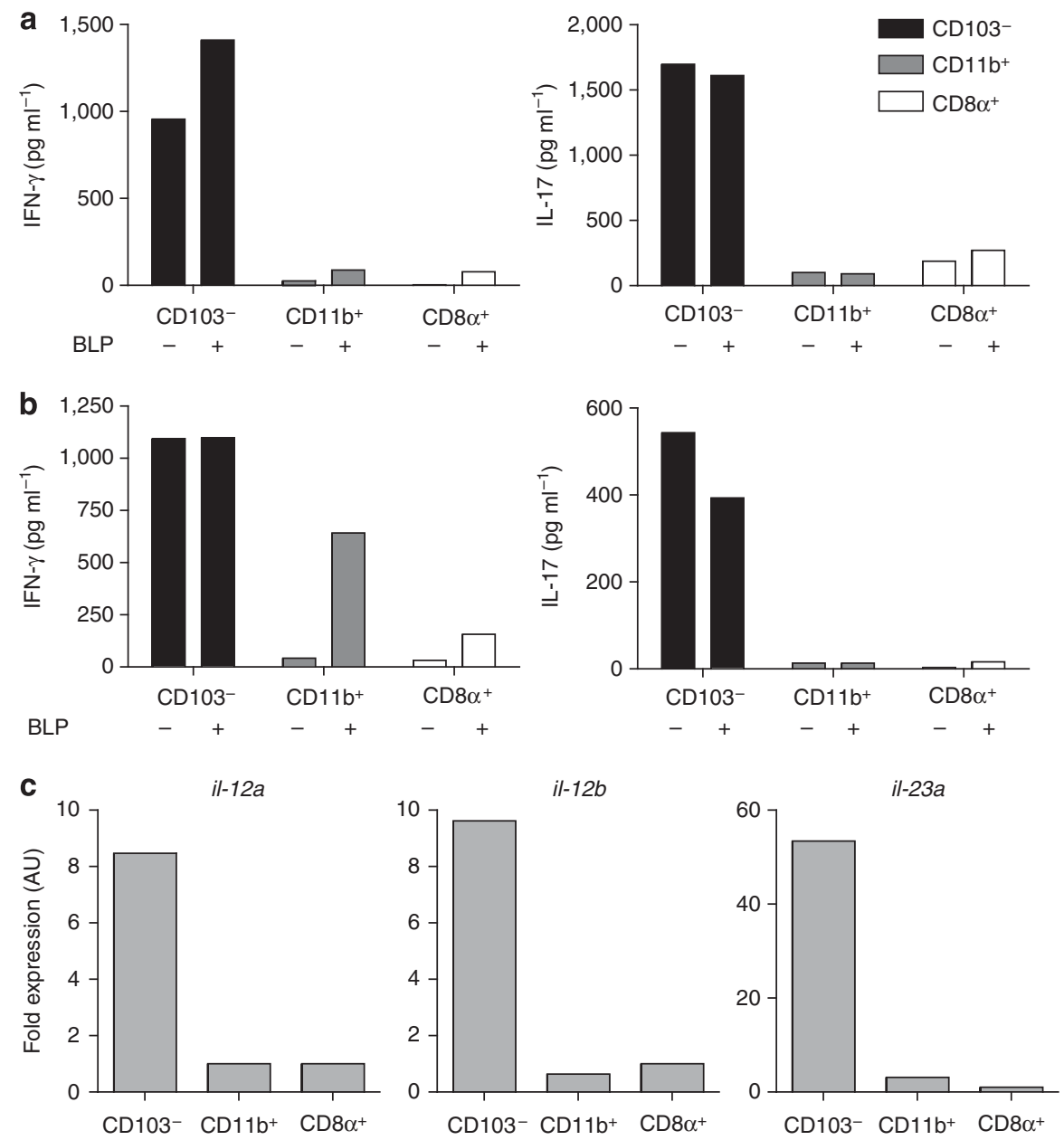

Figure 4 CD103- LDCs (lymph-borne dendritic cells) induce the differentiation of interferon (IFN)- $\gamma$ and interleukin (IL)-17-producing T cells. LDC subsets were sorted and cultured for $2 \mathrm{~h}$ with $2 \mathrm{mg} \mathrm{ml}^{-1}$ of ovalbumin protein with or without the addition of $2.5 \mu \mathrm{g} \mathrm{ml}^{-1}$ of bacterial lipoprotein. DCs were then washed and co-cultured for 3 days at 1:8 DC:T cell ratio with $10^{5}$ sorted (a) naive CD62L ${ }^{+}$OT-2 or (b) OT-1 T cells. IFN- $\gamma$ and IL-17 productions were assessed by luminex. Data are presented as mean of three replicates. (c) Expression of mRNA encoding IL-12p35, IL-12p40, and IL-23p19 in LDC subsets following overnight culture with $10 \mu \mathrm{g} \mathrm{ml}^{-1}$ of anti-CD40 mAb was assessed by quantitative real-time PCR. Data were normalized to the expression of the housekeeping gene HPRT (hypoxanthine-guanine phosphoribosyltransferase) and presented as relative expression (arbitrary units (AU)). All data are representative of two independent experiments.

in the LP, the only previous study of afferent intestinal lymph detected exiguous numbers of these cells, ${ }^{4}$ and hence, they are generally considered to be sessile intestinal macrophages. ${ }^{13}$ Despite sharing some phenotypic characteristics of macrophages, including the expression of the fractalkine receptor $\mathrm{CX}_{3} \mathrm{CR} 1, \mathrm{CD} 103^{-}$LDCs are bona fide DCs; they are highly efficient at priming naive $\mathrm{T}$ cells and continuously migrate from tissue to draining LNs. Crucially, cells with the same surface phenotype are present in the SI LP and express high levels of CCR7 mRNA (Figure 5).

Furthermore, these intestine-derived $\mathrm{CD} 103^{-}$DCs share important functional and phenotypic properties with $\mathrm{CD}_{103}{ }^{+}$ LDCs. All LDC subsets were able to present antigen to naive $\mathrm{T}$ cells and induce CCR9 expression of dividing T cells. Importantly, $\mathrm{CD} 103^{-}$DCs comprise two distinct subsets, separated by their expression of $\mathrm{CD} 11 \mathrm{~b}$ and $\mathrm{CX}_{3} \mathrm{CR} 1$, and by their distinct anatomical origins. $\mathrm{CD}_{103^{-}} \mathrm{CD}_{11 \mathrm{~b}^{+}}$
CX3CR $1^{\text {int }}$ DCs are present in normal numbers in ROR $\gamma \mathrm{t}^{-/-}$ mice, indicating that they mainly reside in the villus LP. Conversely, the CD103- ${ }^{-} \mathrm{CD} 11 \mathrm{~b}^{-} \mathrm{CX} 3 \mathrm{CR} 1^{-} \mathrm{DCs}$ are absent from the intestine of $\mathrm{ROR} \gamma \mathrm{t}^{-1-}$ mice and are therefore likely to mainly derive from the organized intestinal lymphoid tissues such as the Peyer's patches and isolated lymphoid follicles.

Crucially, cells of a similar phenotype to all four LDC subsets were detectable in the SI LP of steady-state mice and were expanded to a similar extent in the LP and intestinal lymph by treatment with Flt3L. Additionally, all four LP DC subsets expressed Flt3 mRNA at a markedly higher level than intestinal macrophages. Therefore, all the LP DCs and LDCs we describe here are responsive to Flt3L, whereas LP MФs are not. Taken together, with the fact that the LPDC populations all express 100-fold higher levels of Flt3 mRNA than LP MФs, these data further indicate that LDC and LP DC populations are distinct 


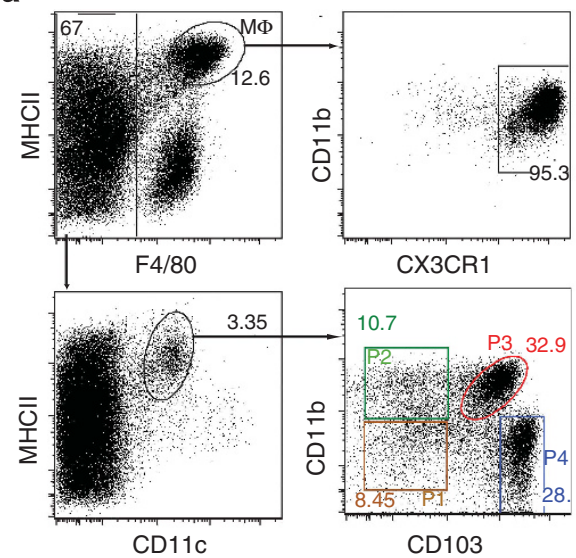

b
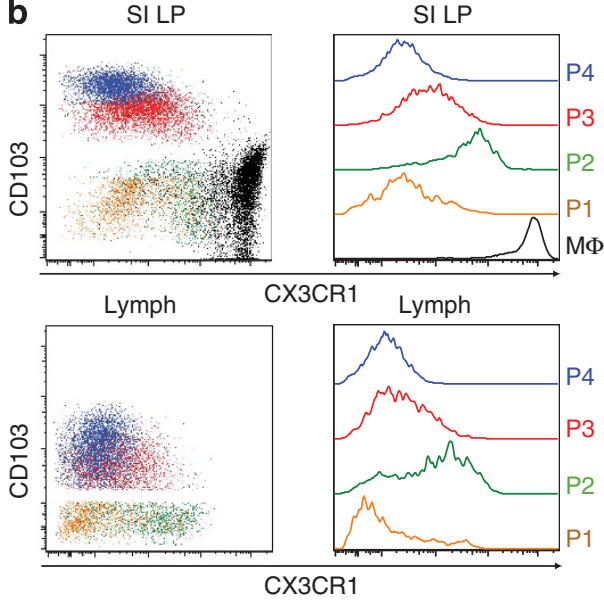

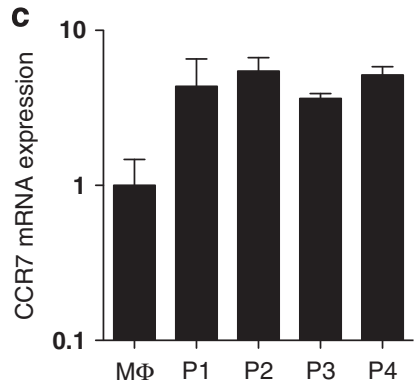

d
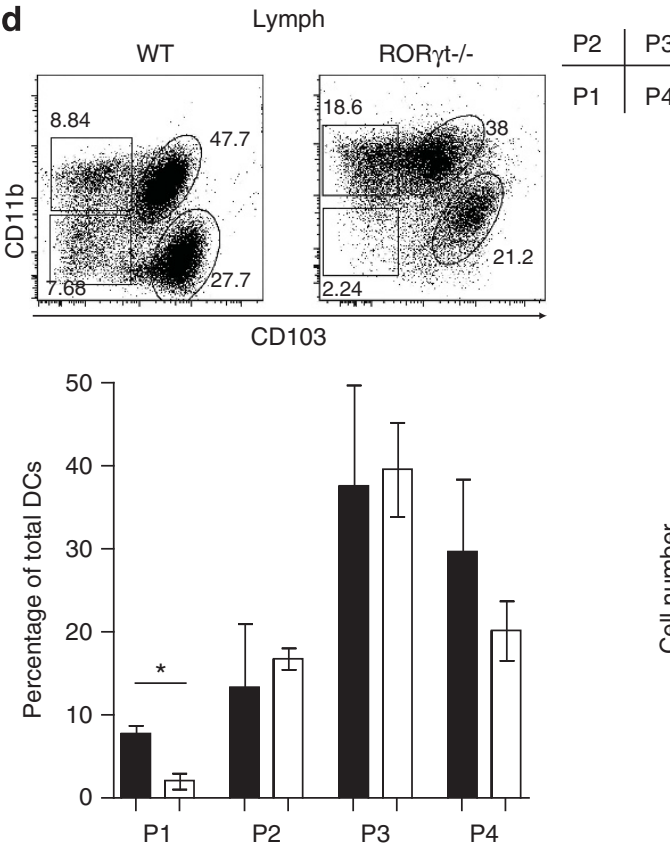

SI LP

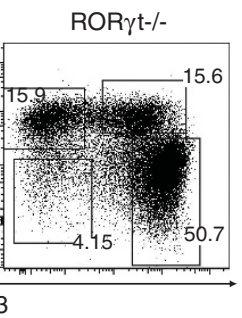

CD103

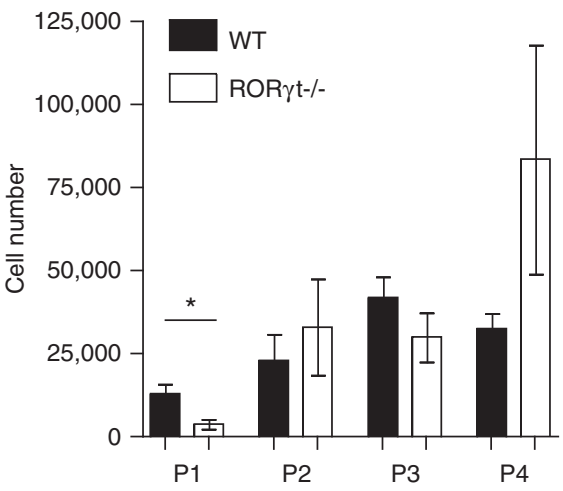

e
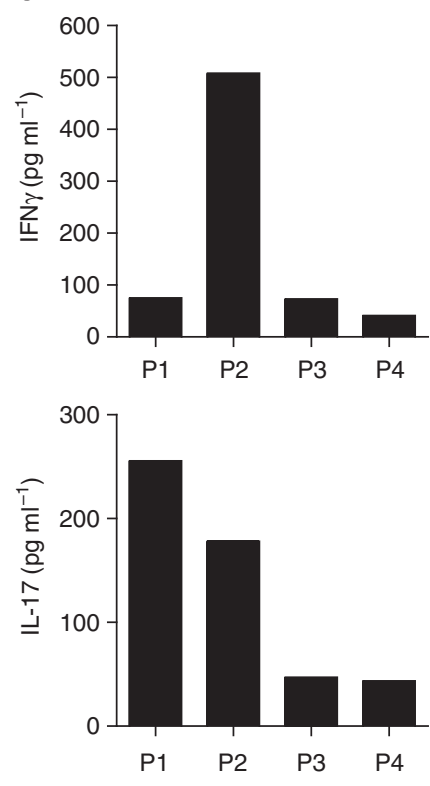

Figure 5 Functionally and anatomically distinct subpopulations of CD103- dendritic cells (DCs) in intestinal lamina propria (LP) and lymph. Small intestine LP (SI LP) cells were isolated as described in the Methods section and the lymph collected by thoracic duct cannulation of mesenteric lymphadenectomy (MLNx) mice. Cells were analyzed by flow cytometry. (a) LP cells from $\mathrm{CX}_{3} \mathrm{CR} 1^{\text {gfp/+ }}$ mice were isolated and analyzed by flow cytometry. Single cells were gated based on physical characteristics and live leukocytes identified as 7AAD- CD45 ${ }^{+}$cells (not shown). Macrophages were identified as $\mathrm{F} 4 / 80^{+}$cells with high expression of major histocompatibility complex II (MHCII; MФ). Macrophages universally express CD11b and high levels of $\mathrm{CX}_{3} \mathrm{CR} 1-\mathrm{GFP}$ (green fluorescent protein). Among F4/80 ${ }^{\mathrm{lo}}$ cells, $\mathrm{MHCI}{ }^{\mathrm{hi}} \mathrm{CD} 11 \mathrm{c}^{+}$cells were gated as DCs, and further split into

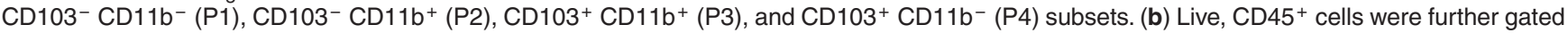

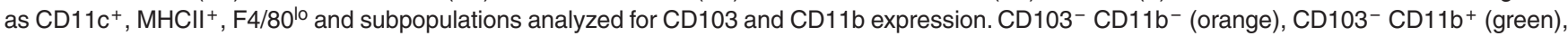
$\mathrm{CD}_{103}{ }^{+} \mathrm{CD} 11 \mathrm{~b}^{+}$(red), and CD103+ ${ }^{+} \mathrm{CD} 11 \mathrm{~b}^{-}$(blue) cells were analyzed for level of GFP expression in the SI LP (top) and pseudo-afferent intestinal lymph (bottom). The black histogram denotes $\mathrm{CX}_{3} \mathrm{CR} 1 \mathrm{GFP}$ expression in F4/80 hi MHCII+ macrophages in the SI LP. (c) Intestinal LP cells were gated as in (a) and purified by fluorescence-activated cell sorter. Quantitative real-time PCR was used to determine the relative expression of CCR7 mRNA, normalized to the housekeeping gene HPRT (hypoxanthine-guanine phosphoribosyltransferase). (d) SI LP and pseudo-afferent lymph cells from $\mathrm{ROR} \gamma \mathrm{t}^{-/-}$mice were isolated and analyzed by flow cytometry. Representative plots show lymph (left) or SI LP DCs (right) gated as in (a) from wild-type (WT) or ROR $\gamma \mathrm{t}^{-/-}$mice. Graphs represent the percentage of each subset among lymph DCs (LDCs; left) or the total number of cells for each DC subset in the SI LP (right). Data are represented as mean \pm s.d. and are from two independent experiments. Asterisks denote statistical significance $\left({ }^{*} P<0.05\right)$. (e) Four LDC subsets were sorted and cultured for $2 \mathrm{~h}$ with $2 \mathrm{mg} \mathrm{ml}^{-1}$ of ovalbumin protein. DCs were then washed and co-cultured for 3 days at 1:8 DC:T cell ratio with $10^{5}$ sorted naive CD62L+ OT-2 T cells. Interferon (IFN)- $\gamma$ and interleukin (IL)-17 concentrations in the supernatants were assessed by luminex. Data are representative of three $(\mathbf{a}, \mathbf{b})$ or two $(\mathbf{c}, \mathbf{e})$ independent experiments.

from LP MФs. Interestingly, the Flt3L-induced expansion of the $\mathrm{LP}$ and lymph $\mathrm{CD} 103^{+} \mathrm{CD} 11 \mathrm{~b}^{+}$compartment was much less pronounced than either the $\mathrm{CD} 103^{-}$or $\mathrm{CD} 8 \alpha^{+}$DCs. Thus, the development of $\mathrm{CD}_{103}{ }^{+} \mathrm{CD} 11 \mathrm{~b}^{+}$intestinal DCs may require an additional growth factor, independent of Flt3 signaling, as previously suggested. ${ }^{3}$ 

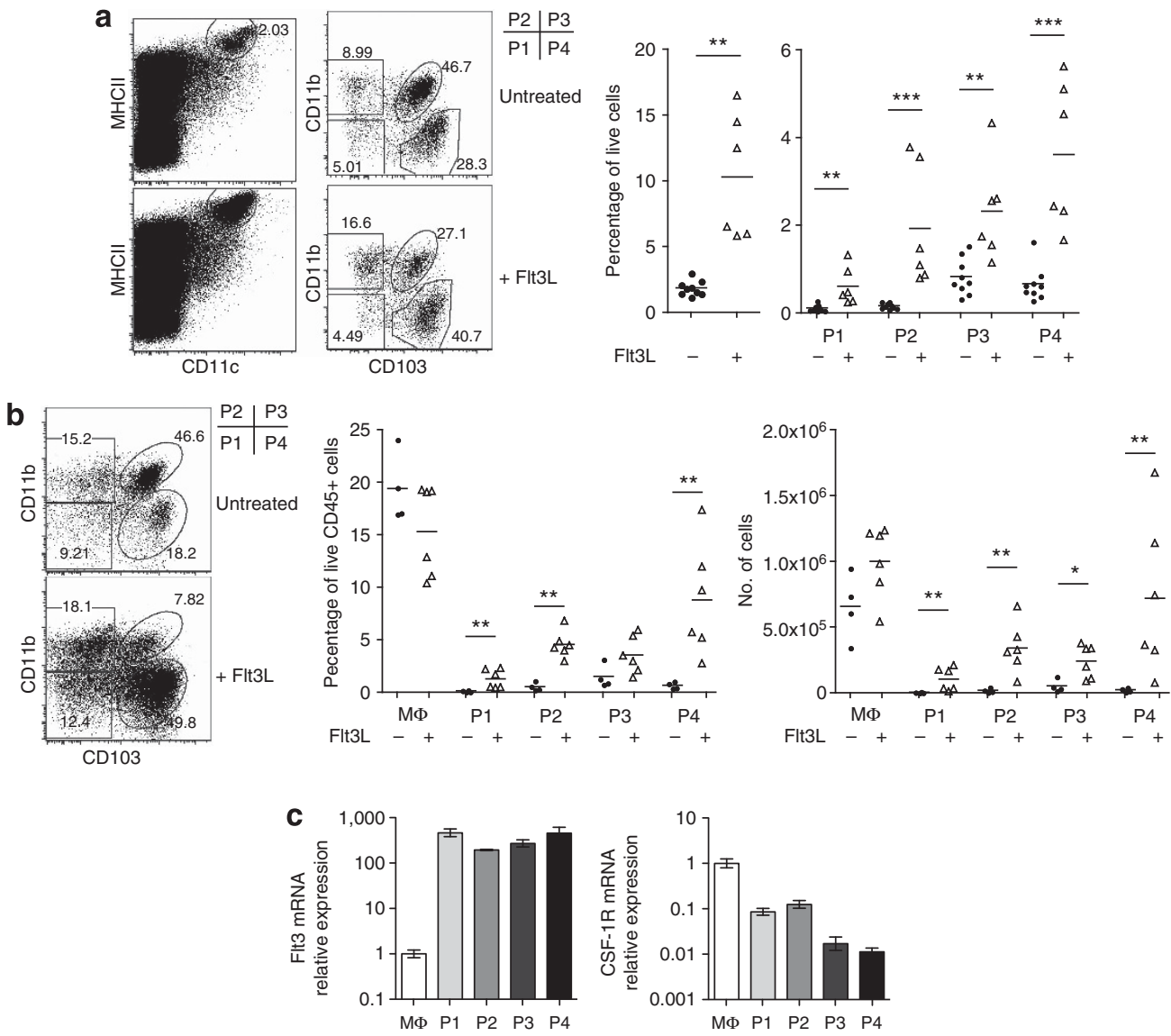

Figure 6 Shared ontogeny of CD103- and CD103+ intestinal dendritic cells (DCs). (a) Mesenteric lymphadenectomy (MLNx) or (b) normal C57BI6 mice were injected intraperitoneally with $10 \mu \mathrm{g}$ of recombinant hFIt3L daily for 9 days. (a) Mice were cannulated at day 9 and the lymph cells analyzed by flow cytometry. Representative plots show the proportion of lymph DC (LDC) cells (left) and the proportion of each subset within the DC gate with (open triangles) or without (filled circles) fms-like tyrosine kinase 3 ligand (Flt3L) treatment. Graphs show the proportion of total LDCs (left) and the three LDC subsets (right) among live cells in untreated or Flt3L-treated mouse lymph. (b) Lamina propria cells were analyzed by flow cytometry and the subsets were gated as in Figure 5a. Plots were gated on live $\mathrm{CD}_{4} 5^{+} \mathrm{CD} 11 \mathrm{c}^{+} \mathrm{MHCll}^{+}$(major histocompatibility complex II) F4/80- cells and show the proportion of each DC subset. The graphs represent the proportion of each subset within the CD45 $7 A A D^{-}$compartment (left) or the total number of cells (right). Each point in (a) and (b) represents a biological replicate. Results were analyzed by Mann-Whitney $U$ test; asterisks denote statistical significance $\left({ }^{\star} P<0.05\right.$, $\left.{ }^{\star \star} P<0.01,{ }^{\star * \star} P<0.001\right)$. (c) Small intestine LP macrophages and four DC subsets were gated as in Figure 5a and sorted by fluorescence-activated cell sorter. Quantitative real-time PCR was used to assess the levels of Flt3 and colonystimulating factor 1 receptor (CSF-1R) mRNA expression, normalized to the expression of the housekeeping gene HPRT (hypoxanthine-guanine phosphoribosyltransferase). The graphs are representative of two independent experiments.

Interestingly, $\mathrm{CD}_{103}{ }^{+}$and $\mathrm{CD} 103^{-}$LDCs had distinct effects on the differentiation of primed T lymphocytes. Although both $\mathrm{CD}_{103}{ }^{+}$LDCs subsets induced naive T cell proliferation, they only induced IFN $-\gamma$ production in proliferating $\mathrm{T}$ cells after activation by a Toll-like receptor ligand. These observations are consistent with previous reports, demonstrating that steadystate $\mathrm{CD}_{103^{+}}$DCs in the SI LP ${ }^{8,9,29}$ and rat intestinal lymph ${ }^{30}$ induce inflammatory cytokine production following Toll-like receptor activation. Conversely, $\mathrm{CD} 103^{-}$DCs expressed higher levels of IL-12 and IL-23 mRNA and induced IFN- $\gamma$ and IL-17 production from proliferating $\mathrm{T}$ cells even in the absence of Tolllike receptor stimulation. Coupled with their ability to confer gut-tropism to effector cells, priming by $\mathrm{CD}_{103^{-}}$intestinal DCs is likely to represent an important mechanism for the initiation of gut-specific adaptive immune responses. In addition, IL-23 and IL-17 have a well-defined role in the induction of inflammatory responses in the gut. ${ }^{31,32}$ Further functional analysis revealed that although both populations of $\mathrm{CD}_{103^{-}}$DCs were able to induce IL-17 production from T cells in the steady state, only the $\mathrm{CD} 103^{-} \mathrm{CD} 11 \mathrm{~b}^{+} \mathrm{CX} 3 \mathrm{CR} 1^{\text {int }} \mathrm{DC}$ s were able to induce IFN- $\gamma$. Interestingly, whereas most data on steady-state intestinal DCs indicate that their function is tolerogenic, a role for intestinal CD11 $\mathrm{c}^{+} \mathrm{MHCII}^{+} \mathrm{CD} 11 \mathrm{~b}^{+} \mathrm{LP}$ DCs in the induction of IFN $-\gamma$ and IL-17 has previously been proposed. ${ }^{33}$ The authors described a heterogeneous population that was largely $\mathrm{CD}_{103^{-}} \mathrm{CD}_{11 \mathrm{~b}^{+}}$and is likely to have contained at least some macrophages. Here, we have combined detailed phenotyping of intestinal populations with analysis of lymph cells, revealing bona fide IFN- $\gamma$ - and IL-17-inducing DCs within this CD11c ${ }^{+}$ $\mathrm{CD} 11 \mathrm{~b}^{+}$population.

Recently, a small population of colonic CD $11 \mathrm{c}^{+} \mathrm{CX} 3 \mathrm{CR} 1^{\text {int }}$ cells has been identified, which share some phenotypic 
characteristics with our LDCs. These colonic cells increase in number after induction of experimental colitis. ${ }^{25}$ It is, therefore, possible that immunogenic DCs are maintained in low numbers in intestinal tissues in the steady state, and are rapidly recruited upon the disruption of intestinal homeostasis.

Here, we offer a definitive characterization of all migrating intestinal DCs and describe, for the first time, a specialized intestinal $\mathrm{CD} 103^{-}$DC subset capable of inducing IFN- $\gamma$ and IL-17 production from naive T cells. Importantly, these $\mathrm{CD} 103^{-} \mathrm{DCs}$ confer gut-tropism to differentiating $\mathrm{T}$ cells, and may therefore represent an important mechanism for the induction of immune responses in the intestinal mucosa. Despite the presence of these immunostimulatory CD103- DCs in the steady state, the balance of the intestinal immune system favors the maintenance of tolerance. This may reflect the fact that $\mathrm{CD}_{103}{ }^{-} \mathrm{DCs}$ are present in much lower numbers than the tolerogenic $\mathrm{CD} 103^{+} \mathrm{DCs}$. We suggest that the balance between $\mathrm{CD} 103^{-} \mathrm{DCs}, \mathrm{CD} 103^{+} \mathrm{DCs}$, and intestinal macrophages is critical for maintaining intestinal immune homeostasis. Therefore, investigating how the functions of $\mathrm{CD} 103^{-}$and $\mathrm{CD} 103^{+}$LDCs change in response to pathogenic or inflammatory stimuli will provide essential insights into the development of intestinal immunopathology and the initiation of immune responses against intestinal pathogens. Finally, targeting $\mathrm{CD}_{103^{-}}$intestinal DCs may prove to be an important strategy for enhancing immune responses to orally administered vaccines.

\section{METHODS}

Animals. C57/B16 mice were purchased from Harlan and maintained in individually ventilated cages. OT-1, OT-2, ROR $\gamma \mathrm{t}^{-1-}$ (originally from Prof. Dan Littman), and $\mathrm{CX}_{3} \mathrm{CR} 1^{\mathrm{GFP} /+}$ mice (originally from Dr Steffen Jung) were bred and maintained under specific pathogen-free conditions at the Central Research Facility, Glasgow, United Kingdom. All procedures were approved by the local ethical committee and conducted under licenses issued by the UK Home Office.

Surgical procedures. Mesenteric lymphadenectomy and thoracic duct cannulation procedures were modified from the established protocols. ${ }^{17}$ Mesenteric lymphadenectomy was performed on 6-week-old male mice by laparotomy and blunt dissection. Six weeks later, mice were fed $0.2 \mathrm{ml}$ olive oil to visualize the lymphatics, and the thoracic lymph duct was cannulated by the insertion of a polyurethane cannula $(2 \mathrm{Fr}$, Linton Instrumentation, Diss, UK). Lymph was collected in phosphate-buffered saline with $20 \mathrm{U} \mathrm{ml}^{-1}$ of heparin sodium (Wockhardt UK, Wrexham, $\mathrm{UK}$ ), on ice, for up to $16 \mathrm{~h}$. During surgical procedures the animals were maintained under inhalation anesthesia with Isoflurane (Abbot Animal Health, Abbott Park, IL).

Reagents. Cells were cultured in RPMI 1640, supplemented with $100 \mathrm{U} \mathrm{ml}^{-1}$ penicillin, $100 \mu \mathrm{g} \mathrm{ml}^{-1}$ streptomycin, $2 \mathrm{~mm} \mathrm{~L}$-glutamine, $5 \%$ fetal calf serum (all from Invitrogen, Paisley, UK), and 50 $\mu \mathrm{M} 2$-mercaptoethanol (Sigma-Aldrich, St Louis, MO). In some experiments, $2.5 \mu \mathrm{g} \mathrm{ml}^{-1}$ bacterial lipoprotein (Pam3CSK4; Invivogen, San Diego, CA) was used to activate the DCs in culture. Recombinant human Flt3L (Amgen, Seattle, WA) was injected intraperitoneally at $10 \mu \mathrm{g}$ per mouse per day for 9 days.

Antibodies. Fluorochrome- or biotin- conjugated monoclonal antibodies to mouse antigens CD11b (M1/70), CD11c (HL3), CD40 (3/23), CD45 (RA3-6B2), CD80 (16-10A1), CD86 (GL1), CD172a (P84), Integrin $\beta 7$
(FIB27), and Siglec F (E50/2440) were from BD Biosciences (Oxford, UK). The monoclonal Abs to mouse antigens CD4 (RM4-5), CD8 $\alpha$ (536.7), CD19 (6D5), CD103 (2E7), CD44 (IM7), and CD62L (MEL-14) were from Biolegend (San Diego, CA). The I-A/I-E MHCII (M5/114.15.2) and F4/80 (BM8) Abs were purchased from eBioscience (San Diego, CA). The PDCA-1 and the agonistic anti-CD40 antibody (FGK45.5) were purchased from Miltenyi Biotec (Auburn, CA). Streptavidin Qdot-605 was purchased from Invitrogen. The Viaprobe dead cell exclusion dye (7AAD) and mouse isotype control antibodies, conjugated to appropriate fluorochromes, were purchased from BD Biosciences. CCR9 staining was detected with the 7E7 antibody (gift from Oliver Pabst, MHH Hanover), and a secondary goat anti-rat Ig antibody (BD Biosciences). Staining for aldehyde dehydrogenase was performed using the ALDEFLUOR kit (StemCell Technologies, Grenoble, France) according to the manufacturer's instructions.

Cell isolation. Thoracic duct leukocytes were collected on ice in phosphate-buffered saline with $20 \mathrm{U} \mathrm{ml}^{-1}$ Heparin, passed through a $40-\mu \mathrm{m}$ cell strainer (BD Biosciences), and red blood cells lysed with ACK lysis buffer (Sigma-Aldrich). Cells were stained and analyzed by flow cytometry or sorted by fluorescence-activated cell sorter using the FACSAria cell sorter (BD Biosciences).

Small intestines were flushed with Hank's balanced salt solution $2 \%$ fetal calf serum and the Peyer's patches excised. The intestines were opened longitudinally and cut into $0.5-\mathrm{cm}$ segments, which were incubated twice in Hank's balanced salt solution with $2 \mathrm{~mm}$ EDTA at $37^{\circ} \mathrm{C}$ with shaking for $20 \mathrm{~min}$. Supernatants were discarded and the tissue digested with $1 \mathrm{mg} \mathrm{ml}^{-1}$ of collagenase VIII (Sigma-Aldrich) at $37^{\circ} \mathrm{C}$ with shaking for $15 \mathrm{~min}$. Cells were passed through a $40-\mu \mathrm{m}$ cell strainer and stained for flow cytometry.

Flow cytometry. Cell surface staining was performed in phosphate-buffered saline with $2 \%$ fetal calf serum and $10 \mathrm{mM}$ EDTA for $30 \mathrm{~min}$ on ice. Where biotin-conjugated antibody was used, cells were further stained with a streptavidin-fluorochrome conjugate for $15 \mathrm{~min}$. Samples were acquired on LSRII (BD Biosciences) or MACSQuant (Miltenyi Biotec) flow cytometers or sorted and analyzed by the FACSAria cell sorter (BD Biosciences). Acquired data was analyzed using FlowJo software (version 9.3.1; Tree Star, Ashland, OR).

Microscopy. Cells were centrifuged (300 rpm, $5 \mathrm{~min}$ ) onto poly-L-Lysine coated slides (VWR International, Radnor, PA) and stained using the Rapid Romanowsky staining kit (Thermo Fisher Scientific, Waltham, $\mathrm{MA})$. Images were obtained using a light microscope at $\times 40$ magnification and were analyzed and archived using cell $\wedge \mathrm{B}$ software (Olympus, Tokyo, Japan).

Proliferation assay. Sorted LDCs were pulsed with $2 \mathrm{mg} \mathrm{ml}^{-1}$ of ovalbu$\min$ (Worthington, Lakewood, NJ) for $2 \mathrm{~h}$ at $37^{\circ} \mathrm{C}$ and then extensively washed. They were cultured at varying ratios with $10^{5} \mathrm{CFSE}$-labeled naive OT- 1 or OT- 2 cells at $37^{\circ} \mathrm{C}$ for 3 days. CFSE dilution was assessed by flow cytometry.

Cytokine detection. DCs and T cells were co-cultured for 3 days, then incubated for $4 \mathrm{~h}$ with phorbol 12 -myristate 13 -acetate and Ionomycin (both from Sigma-Aldrich), and the supernatants harvested. Concentrations of IFN- $\gamma$, IL-17, IL-10, and IL- 4 were assessed by the Milliplex cytokine bead assay (Millipore, Billerica, MA) according to the manufacturer's instructions. Minimum detectable concentrations for all cytokines were $<5 \mathrm{pg} \mathrm{ml}^{-1}$.

RNA extraction. RNA was extracted using the MicroRNA kit (Qiagen, Venlo, Netherlands) according to the manufacturer's instructions. Contaminating genomic DNA was removed using the DNA-free kit (Qiagen). RNA was reverse transcribed using Superscript First Strand kit (Invitrogen). 
Real-time quantitative PCR (qPCR). cDNA was examined for the frequency of different transcripts using qPCR. IL-12 and IL-23 subunits were analyzed using the Taqman probe system. All qPCR Taqman reactions were performed in $20 \mu \mathrm{l}$ volumes using colorless master mix (Promega, Fitchburg, WI) and primer/probe sets designed and validated by Applied Biosystems (Foster City, CA; Mm00518984_m1, Mm00434165_m1, Mm00434174_m1, and Mm00446968_m1). Fluorescence levels were detected and analyzed using the $7900 \mathrm{HT}$ Fast system (Applied Biosystems). All other qPCR reactions were performed using the Brilliant III Ultra Fast SYBR qPCR master mix (Agilent Technologies, Santa Clara, CA). Primers used were HPRT: forward GCTG ACCTGCTGGATTACATTAA, reverse TGATCATTACAGTAGCTCTT CAGTCTGA; CCR7: forward ATTGCTGCTGAGGGAAGAG, reverse ACTTTTGGCTGTCGTTTTGG; colony-stimulating factor 1 receptor: forward GCATACAGCATTACAACTGGACCTA CC, reverse CAGGACATCAGAGCCATTCACAG; and Flt3: forward GGTTTAAAGCGTACCCACGA, reverse GAACTGGGCG TCATCATTTT. Relative quantification was determined using the $\Delta \Delta \mathrm{Ct}$ method and normalized to expression of the housekeeping gene HPRT.

Statistical analysis. For comparison of means between two groups, the data were analyzed using a Student's $t$-test unless otherwise indicated. For comparisons involving more than two data sets, an analysis of variance was used. $P$-values $<0.05$ were considered significant and Bonferroni post-test was performed on the data sets. All statistical analysis was performed using GraphPad Prism and Microsoft Excel.

SUPPLEMENTARY MATERIAL is linked to the online version of the paper at http://www.nature.com/mi

\section{ACKNOWLEDGMENTS}

We thank Dr Gordon MacPherson and Dr Andrew MacDonald for critical reading of the manuscript, Dr William Agace for providing the $\mathrm{CX}_{3} \mathrm{CR}_{1} \mathrm{GFP} /+$ animals, and Prof. Peter Lane for providing the ROR $\gamma \mathrm{t}^{-/-}$ mice. We also thank Laura Ford for technical assistance and the University of Glasgow Flow Cytometry Core Facility for assistance with cell sorting. VC was funded by a Medical Research Council award to SWFM; AA, CLS, and AMM were funded by the Wellcome Trust. SAH was supported by a Capacity Building Award in Integrative Mammalian Biology funded by the BBSRC, BPS, KTN, MRC and SFC, AstraZeneca, GlaxoSmithKline, and Pfizer.

\section{DISCLOSURE}

The authors declared no conflict of interest.

(C) 2013 Society for Mucosal Immunology

\section{REFERENCES}

1. Pabst, O. \& Bernhardt, G. The puzzle of intestinal lamina propria dendritic cells and macrophages. Eur. J. Immunol. 40, 2107-2111 (2010).

2. Hadis, U. et al. Intestinal tolerance requires gut homing and expansion of FoxP3(+) regulatory T cells in the lamina propria. Immunity 34, 237-246 (2011).

3. Bogunovic, M. et al. Origin of the lamina propria dendritic cell network. Immunity 31, 513-525 (2009).

4. Schulz, O. et al. Intestinal CD103+, but not CX3CR1+, antigen sampling cells migrate in lymph and serve classical dendritic cell functions. J. Exp. Med. 206, 3101-3114 (2009).

5. Coombes, J.L. et al. A functionally specialized population of mucosal CD103+ DCs induces Foxp3+ regulatory T cells via a TGF-\{beta $\}$ and retinoic acid dependent mechanism. J. Exp. Med. 204, 1757-1764 (2007).

6. Sun, C.M. et al. Small intestine lamina propria dendritic cells promote de novo generation of Foxp3T reg cells via retinoic acid. J. Exp. Med. 204, 1775-1785 (2007).

7. Johansson-Lindbom, B. et al. Functional specialization of gut CD103+ dendritic cells in the regulation of tissue-selective T cell homing. J. Exp. Med. 202, 1063-1073 (2005).
8. Uematsu, S. et al. Regulation of humoral and cellular gut immunity by lamina propria dendritic cells expressing Toll-like receptor 5 . Nat. Immunol. 9, 769-776 (2008).

9. Fujimoto, K. et al. A new subset of CD103+CD8\{alpha\}+ dendritic cells in the small intestine expresses TLR3, TLR7, and TLR9 and induces Th1 response and CTL activity. J. Immunol. (2011).

10. Jakubzick, C. et al. Lymph-migrating, tissue-derived dendritic cells are minor constituents within steady-state lymph nodes. J. Exp. Med. 205, 2839-2850 (2008).

11. Siddiqui, K.R., Laffont, S. \& Powrie, F. E-cadherin marks a subset of inflammatory dendritic cells that promote T cell-mediated colitis. Immunity 32, 557-567 (2010).

12. Niess, J.H. et al. CX3CR1-mediated dendritic cell access to the intestinal lumen and bacterial clearance. Science 307, 254-258 (2005).

13. Persson, E.K., Jaensson, E. \& Agace, W.W. The diverse ontogeny and function of murine small intestinal dendritic cell/macrophage subsets. Immunobiology 215, 692-697 (2010).

14. Ginhoux, F. et al. The origin and development of nonlymphoid tissue CD103+ DCs. J. Exp. Med. 206, 3115-3130 (2009).

15. Varol, C. et al. Intestinal lamina propria dendritic cell subsets have different origin and functions. Immunity 31, 502-512 (2009).

16. Weber, B., Saurer, L., Schenk, M., Dickgreber, N. \& Mueller, C. CX3CR1 defines functionally distinct intestinal mononuclear phagocyte subsets which maintain their respective functions during homeostatic and inflammatory conditions. Eur. J. Immunol. 41, 773-779 (2011).

17. Milling, S.W., Jenkins, C.\& MacPherson, G. Collection of lymph-borne dendritic cells in the rat. Nat. Protoc. 1, 2263-2270 (2006).

18. Rhodes, J.M. Isolation of large mononuclear la-positive veiled cells from the mouse thoracic duct. J. Immunol. Methods 85, 383-392 (1985).

19. Ionac, M. One technique, two approaches, and results: thoracic duct cannulation in small laboratory animals. Microsurgery 23, 239-245 (2003).

20. Milling, S., Yrlid, U., Cerovic, V. \& MacPherson, G. Subsets of migrating intestinal dendritic cells. Immunol. Rev. 234, 259-267 (2010).

21. Yrlid, U. et al. Plasmacytoid dendritic cells do not migrate in intestinal or hepatic lymph. J. Immunol. 177, 6115-6121 (2006).

22. Zhang, J.Q., Biedermann, B., Nitschke, L. \& Crocker, P.R. The murine inhibitory receptor $m S i g l e c-E$ is expressed broadly on cells of the innate immune system whereas mSiglec-F is restricted to eosinophils. Eur. J. Immunol. 34, 1175-1184 (2004).

23. Lutz, M.B. \& Schuler, G. Immature, semi-mature and fully mature dendritic cells: which signals induce tolerance or immunity? Trends Immunol. $\mathbf{2 3}$, 445-449 (2002).

24. Jaensson, E. et al. Small intestinal CD103+ dendritic cells display unique functional properties that are conserved between mice and humans. J. Exp. Med. 205, 2139-2149 (2008).

25. Rivollier, A., He, J., Kole, A., Valatas, V. \& Kelsall, B.L. Inflammation switches the differentiation program of Ly6Chi monocytes from antiinflammatory macrophages to inflammatory dendritic cells in the colon. J. Exp. Med. 209, 139-155 (2012).

26. Jung, S. et al. Analysis of fractalkine receptor CX(3)CR1 function by targeted deletion and green fluorescent protein reporter gene insertion. Mol. Cell. Biol. 20, 4106-4114 (2000).

27. Sun, Z. et al. Requirement for RORgamma in thymocyte survival and lymphoid organ development. Science 288, 2369-2373 (2000).

28. Jang, M.H. et al. CCR7 is critically important for migration of dendritic cells in intestinal lamina propria to mesenteric lymph nodes. J. Immunol. 176, 803-810 (2006).

29. Kinnebrew, M.A. et al. Interleukin 23 production by intestinal

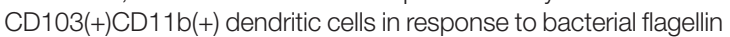
enhances mucosal innate immune defense. Immunity 36, 276-287 (2012).

30. Cerovic, V. et al. Hyporesponsiveness of intestinal dendritic cells to TLR stimulation is limited to TLR4. J. Immunol. 182, 2405-2415 (2009).

31. Maloy, K.J. \& Powrie, F. Intestinal homeostasis and its breakdown in inflammatory bowel disease. Nature 474, 298-306 (2011).

32. Uhlig, H.H. et al. Differential activity of IL-12 and IL-23 in mucosal and systemic innate immune pathology. Immunity 25, 309-318 (2006).

33. Denning, T.L., Wang, Y.C., Patel, S.R., Williams, I.R. \& Pulendran, B. Lamina propria macrophages and dendritic cells differentially induce regulatory and interleukin 17-producing T cell responses. Nat. Immunol. 8, 1086-1094 (2007) 